\title{
DIVERSITY AND DISTRIBUTION OF HERPETOFAUNA IN INSTITUT TEKNOLOGI SUMATERA CAMPUS AREA
}

\author{
RIZKI KURNIA TOHIR*) AND DIYANTI ISNANI SIREGAR \\ Forestry Engineering Study Program, Institut Teknologi Sumatera, Lampung Selatan, 35365, Indonesia \\ *Email: rizki.tohir@rh.itera.ac.id
}

Accepted November 17, 2020 / Approved December 22, 2020

\begin{abstract}
Land use chang ef rubber plantation into ITERA campus area has led to changes in the ecologyof the area. Amphibians an d reptiles, referred as Herpetofauna, are categorized as wild animals that are sensitive to environmental changes and are considered as bio-indicators. Wild conservation activities including herpetofauna is an essential part to the forest campus concept in ITERA. The objective of the study is to analyze the diversity and distribution of herpetofauna. This applied Visual Encounter Survey (VES) with Time Constraint Method and Glue Trap technique. This research was carried out on six observation path and 180 traps. The ecological index analysis consisted of species diversity, evenne ss, ric hne ss, abundance, and community similarity. Twenty-two herpetofauna species were found, including nine amphibians ( 5 families) and 13 reptiles ( 9 families). There was one reptile species with vulnerable conservation status and 3 reptile species included in CITES appendix II. The diversity in dex value $\left(H^{\prime}\right)$ was 2.29; species evenness $(E)$ value was 0.74 ; and species richness value was 3.33 . Amphibian species with the highest abundan ce was Fejervarya cancrivora 1.78 individual/hour of observer, while from the reptile species was Hemidactylus frenatus 0.35 individual/hour of observer. There were 550 herpetofauna encounters, where 8 species could be found on all transects and 6 species could only be found on one tran sect. This research showed that the condition of ITERA habitat currently supported herpetofauna's life and needed conservation activitie s to maintain herpetofauna diversity.
\end{abstract}

Key words: distribution, diversity, herpetofauna, ITERA

\section{INTRODUCTION}

Institut Teknologi Sumatera (ITERA) campus is an area with rapid development at the current moment. Land conversion happened in a place that was once a 275 ha rubber plantation but turned into an office area in 2012 and continued to present. As a new campus that promotes the Smart, Friendly, and Forest Campus concept, conservation programs are needed to support the concept itself. One of the programs is the biodiversity conservation program in ITERA. Land use change is indicated to cause biodiversity composition change. Ecology study learns organism interaction in order to survive in an area by considering the environmental conditions (Hortal et al. 2009). There is an interdependency relationship between biotic and abiotic factors that influence organism species composition within a region (Stein et al. 2014).

Herpetofauna is a group of wildlife inhibiting ITERA area. Herpetofauna spreads in each habitat type, from forests, deserts, and grasslands. However, some types of herpetofauna are only found in certain specific habitats, so it is good to use it as the bio-indicator of environmental change (US Department of Agriculture 2006). Sumatera is rich in biodiversity. According to LIPI, there are at least 254 reptile species and 116 amphibian species in Sumatera. Herpetofauna is a group of reptiles and amphibians that are very vulnerable toward environmental changes (Kusrini 2009). Larson (2014) states that herpetofauna is known to be very vulnerable to environmental change compared to other a nimalia taxa. Qurniawan (2015) states that herpetofauna ecology is significantly influenced by microclimate of specific habitat. There are countless human activities that could degrade the wealth and abundance of reptile and amphibian species, such as agricultural land clearing and illegal logging (Wanger et al. 2009).

The land conversion in ITERA and the development of forest campus require biodiversity conservation activity, one of which is herpetofauna. The study and planning of biodiversity hotspot in ITERA campus is not yet carried out. Hence, a study of herpetofauna diversity and distribution in ITERA Campus for biodiversity database development is needed. This study could be the basic data (time series) to assess the process of campus development that is in concordance to forest campus concept. Therefore, this study aims to a nalyze the data of biodiversity and herpetofauna community distribution in ITERA campus.

\section{RESEARCH METHOD}

This study was conducted in ITERA a rea by $275 \mathrm{ha}$ in August-October 2020. This study was conducted based on sic transects (Figure 1). The data were collected from 07.00-10.00 WIB (Western Indonesia Time) and 19.30-21.30 WIB. The research instruments were headlamp, syringe, surgical instrument, specimen boxes, tally sheet, snake tong, calico pouch, GPS, and camera. The materials were: mouse glue trap, cooking oil, alcohol $90 \%$, battery, clear plastics, and 30 plywood $(40 \times 40 \mathrm{~cm})$. 


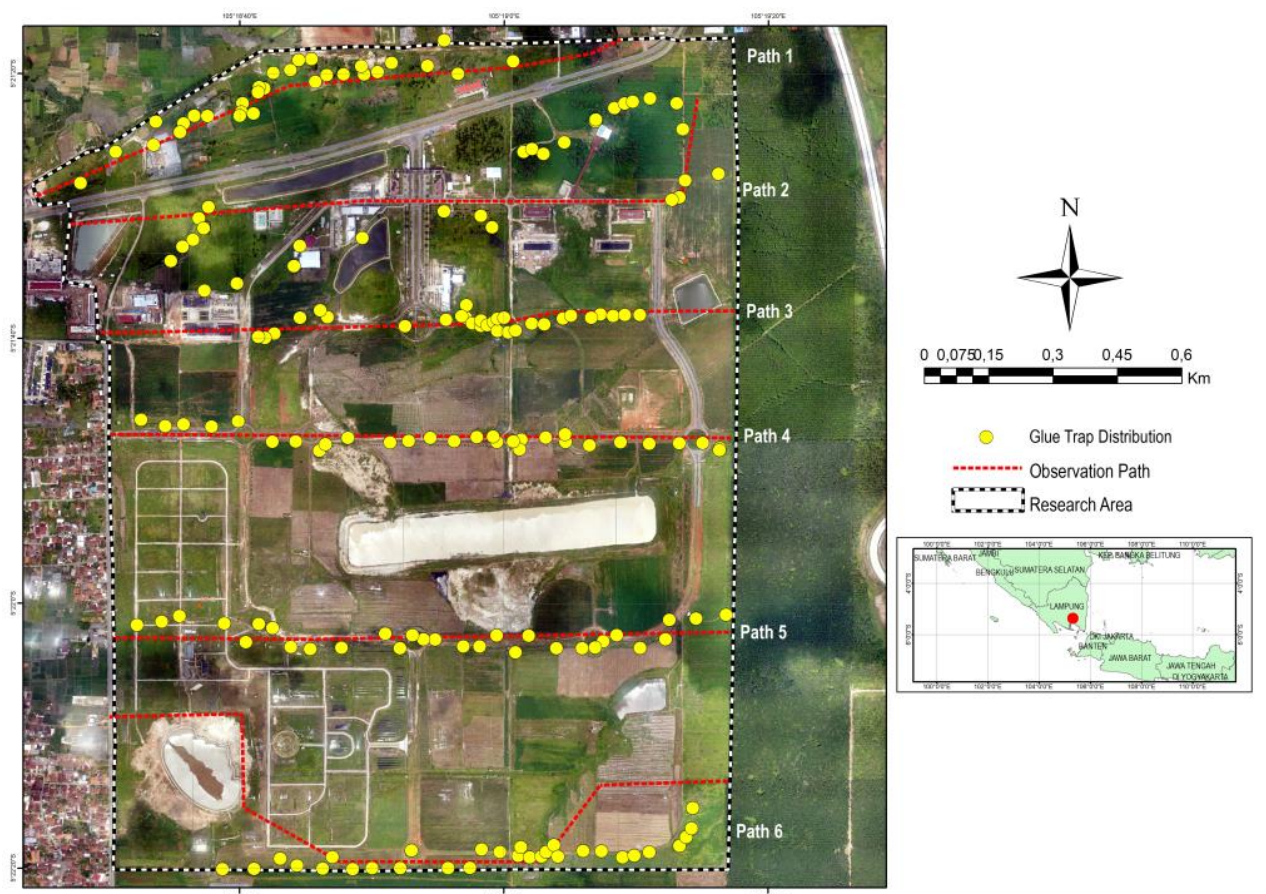

Figure 1 ITERA Campus area, observation path, and trap distribution

The study used two data collection methods, i.e., Visual Encounter Survey (VES) With Time Constraint Method and Glue Trap. VES method is a direct encounter method in the observation path (Kusrini 2019). The observation was done by slowly walking down through the transect to find reptiles and amphibians within two hours (19.30-21.30 WIB). The repetition was done on the following day for as many as two repetitions. The data recording was carried out the collected species, activity, substrate, and coordinates.

Trap method was applied to get herpetofauna that were difficult to catch actively (Kusrini 2019). Glue trap was used to trap several lizards that were hard to catch (Fitch 1992). The glue trap was $40 \times 40 \mathrm{~cm}$ plywood covered with glue and was displayed when the sun rose and was checked before noon. The glue traps were put along the observation path in which the location was possible to be in concordance with the microhabitat of most reptiles active during the day. Thirty traps were distributed on each transect; so there were 180 traps were spread all over the available transects. The trap installation was repeated twice on each transect.

The analysis of herpetofauna distribution was done by analyzing coordinate point with Arc-Map processed program license organizational account of Lea_Itera and organization name of Esri Indonesia Smart Community. Ecology index analysis includes species diversity, species evenness, Margalef species richness, Jackknife species richness, species abundance, and community similarity. Species diversity is an expression that connects number of species to the number of individuals, while evenness index is to identify the community evenness (Kusrini 2019). a. Shannon-Wiener Species Diversity Index (Magguran 1988)

$$
H^{\prime}=-\sum p i \ln p i
$$

Description:

$H^{\prime}=$ species diversity index;

$\mathrm{pi}=$ Abundance value $(\mathrm{ni} / \mathrm{Ni})$

b. Species Evenness Index (Magguran 1988)

$$
\mathrm{E}=\frac{H^{\prime}}{\ln S}
$$

Description:

$\mathrm{E}=$ Degree of species evenness;

$\mathrm{S}=$ Number of species found

c. Species richness index (Magguran 1988)

$$
\operatorname{Dmg}=\frac{S-1^{y}}{\ln N}
$$

Description:

Dmg= Margalef species richness index;

$\mathrm{N}=$ Number of individuals found

d. Jackknife species richness index (Heltse and Foster 1983)

This index is used to estimate the total richness in observation location.

$$
\mathrm{S}=\mathrm{s}+\left(\frac{n-1}{\mathrm{n}}\right)(k)
$$

Description:

$\mathrm{S}=$ Jackknife species richness index;

$\mathrm{s}=$ number of species found;

$\mathrm{n}=$ number of observation path;

$\mathrm{k}=$ number of species found only in one observation path. 
e. Species abundance

$$
\mathrm{K}=\frac{n i}{p i x t i}
$$

Description:

$\mathrm{K}=$ species abundance;

$\mathrm{ni}=$ number of individual type-I;

$\mathrm{pi}=$ number of observers;

$\mathrm{ti}=$ length of observation time.

f. Community similarity

The composition similarity of herpetofauna community was calculated by applying the Jaccard similarity index using the PAST 3.14 program.

\section{RESULT AND DISCUSSION}

\section{Species Composition and Herpetofauna Species Diversity}

This study found 22 herpetofauna species that consist of 9 amphibian species and 13 reptile species (Table 1). The amphibian found was 441 individual of 5 families. As much as 109 individuals from 9 families of reptiles were found in this study. Most IUCN conservation status of herpetofauna species is Least Concern (LC) and Not Evaluated (NE) which meant it still had a safe population. Only one reptile was determined to have Vulnerable (VU) and Appendix II CITES conservation status, i.e., Siebenrockiella crassicollis. According to Fauzi et al. (2020) S. crassicollis species is one of three freshwater turtles exploited in large-scale in South Sumatera and Central Kalimantan to be consumed, processed into medicine, and to be kept as pet. The other two species with CITES II trading status were Naja sumatrana and Malayopython reticulatus. $N$. sumatrana was included into CITES appendix II trading list because it was mostly for its skin and as live specimens (UNEP WCMC 2007). According to Murray-Dickson et al. (2017), M. reticulatus is the most traded species for fashion industry needs and therefore it is included into CITES appendix II.

Table 1 Herpetofauna species in ITERA campus area.

\begin{tabular}{|c|c|c|c|c|c|}
\hline No. & Name of species & Family & IUCN & CITES & Number of individuals found \\
\hline \multicolumn{6}{|c|}{ Amphibian } \\
\hline 1 & Duttaphrynus melanostictus & Bufonidae & $\mathrm{LC}$ & - & 119 \\
\hline 2 & Ingerophrynus biporcatus & Bufonidae & $\mathrm{LC}$ & - & 7 \\
\hline 3 & Fejervarya wasl & Dicroglossidae & $\mathrm{NE}$ & - & 12 \\
\hline 4 & Occidozyga lima & Dicroglossidae & $\mathrm{LC}$ & - & 11 \\
\hline 5 & Kaloula baleata baleata & Mycrohylidae & $\mathrm{NE}$ & - & 2 \\
\hline 6 & Bijurana nicobariensis & Ranidae & $\mathrm{LC}$ & - & 84 \\
\hline 7 & Fejervarya cancrivora & Ranidae & $\mathrm{LC}$ & - & 128 \\
\hline 8 & Hylarana erythraea & Ranidae & $\mathrm{LC}$ & - & 55 \\
\hline 9 & Polypedates leucomystax & Rhacophoridae & $\mathrm{LC}$ & - & 23 \\
\hline \multicolumn{6}{|c|}{ Reptile } \\
\hline 1 & Calotes versicolor & Agamidae & $\mathrm{NE}$ & - & 19 \\
\hline 2 & Ahaetula prasina & Colubridae & $\mathrm{LC}$ & - & 4 \\
\hline 3 & Dendrelaphis pictus & Colubridae & NE & - & 12 \\
\hline 4 & Lycodon capucinus & Colubridae & $\mathrm{LC}$ & - & 2 \\
\hline 5 & Ptyas korros & Colubridae & NE & - & 1 \\
\hline 6 & Bungarus candidus & Elapidae & $\mathrm{LC}$ & - & 2 \\
\hline 7 & Naja sumatrana & Elapidae & $\mathrm{LC}$ & II & 1 \\
\hline 8 & Hemidactylus frenatus & Gekkonidae & $\mathrm{LC}$ & - & 25 \\
\hline 9 & Siebenrockiella crassicollis & Geoemydidae & VU & II & 1 \\
\hline 10 & Takydromus sexlineatus & Lacertidae & $\mathrm{LC}$ & - & 20 \\
\hline 11 & Malayopython reticulatus & Pythonidae & $\mathrm{LC}$ & II & 1 \\
\hline 12 & Eutropis multifasciata & Scincidae & $\mathrm{LC}$ & - & 19 \\
\hline 13 & Varanus salvator & Varanidae & $\mathrm{LC}$ & - & 2 \\
\hline
\end{tabular}

Description: Least Concern (LC), Not Evaluated (NE), Vulnerable (VU) 
The results showed that the dominant family in amphibian class was Ranidae and Bufonidae (Figure 2). There were 267 individuals from Ranidae class. Iskandar (1998); and Irham et al. (2012) state that Ranidae is the widespread family in Indonesia, hence, many of it are found in ITERA area. Bufonidae was the second dominant family from a mphibian class found in rese a rch location, which was 126 individuals. This is in accordance with the research conducted by Kurniati (2008) which states that Bufonidae family can be found in places interrupted by human activities.

The dominant families of the reptile class that were successfully found were Gekkonidae and Lacertidae. Gekkonidae is a dominant family from reptile class with 25 individual species. This also supports the statement of Eprilurahman (2012) who says that Gekkonidae family is a cosmopolite family and can be found around the area of human activity. Lacertidae family is family with 20 individuals. Lacertidae family are widely found because this species lives in plantation and shrubs (Mistar 2008). This suits the habitat condition in ITERA which is dominated by shrubs, and some parts of the habitat are the community's plantation.

The herpetofauna species diversity (H') in ITERA area was 2.29; species evenness (E) was 0.74; and species richness was 3.33 . The index of species diversity, evenness, and richness was the first data taken from ITERA area and could be used to compare other results of time series research in the future. Any kind of construction in ITERA would affect the habitat. Kusrini (2009) says that species richness can increase by the increased habitat diversity. The herpetofauna species abundance (individual/hour of observer) in ITERA is shown in Figure 3. The amphibian class with the highest species abundance was Fejervarya cancrivora by 1.78 individual/hour of observer. While the highest species abundance in reptile class was Hemidactylus frenatus by 0.35 individual/hour of observer.

$F$. cancrivora has high abundance because this species is highly tolerant and adaptive to disturbance (Kurz et al. 2016). Iskandar (1998) agrees that $F$. cancrivora is a frog species often found in paddy field and swamp ecosystems, also near rivers and distributed from lowland to high land by 900 height above sea level. This species is also often found in paddy fields and swamps (Kurniati and Sulistyadi 2017). Paddy fields can be found in some locations in ITERA, especially in path 1. There are also swamps in this area that support the existence of this species.

Hemidactylus frenatus was reptile with the highest abundance found in the research area. H. frenatus was found in ITERA area on trees and usually trapped in glue trap. A research conducted by McKay et al. (2009) finds a similarity that $H$. frenatus species is often found on trees. This species spreads in tropical and subtropical area, including Asia (Goris and Maeda 2004).

The VES method research took 12 days. The data analysis results of addition of species from 12 observations could be seen in Figure 4. Species addition graphic at the beginning of the study tended to increase constantly to day -9 and stuck at day-12. This showed that no more species was found in the research location (ITERA). By calculating the number of species estimation using the Jackknife, the number of herpetofauna in ITERA was 27 species. This still allows the addition of species in ITERA campus area

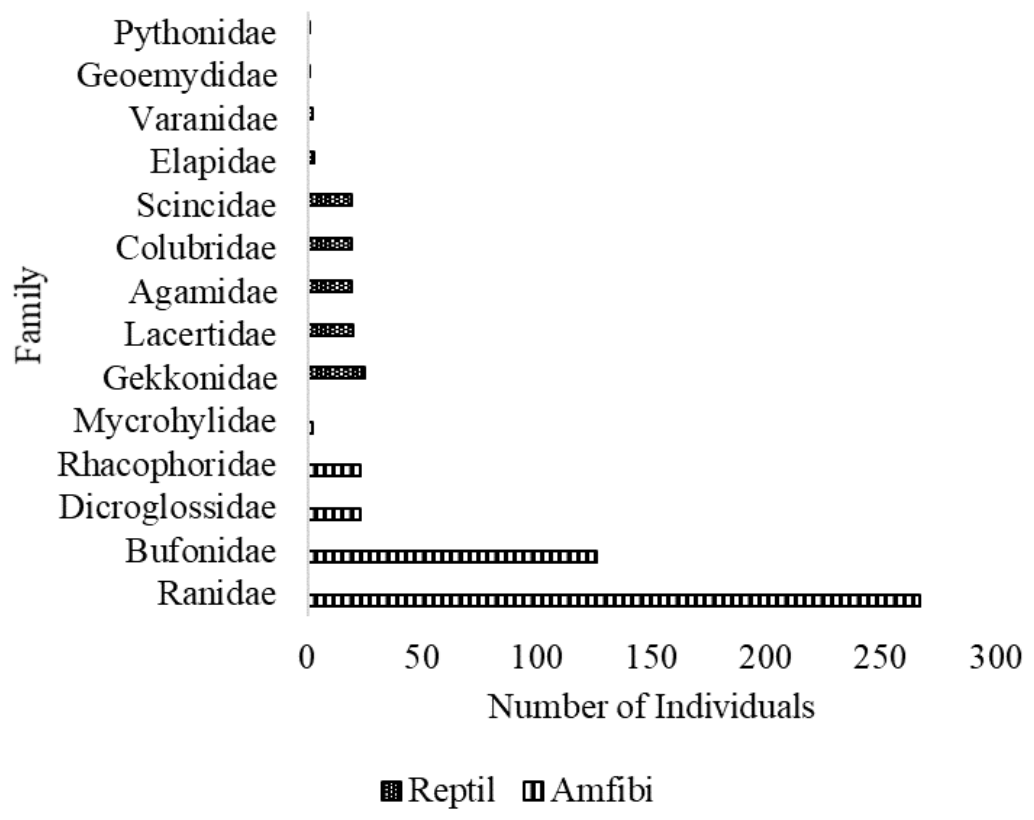

Figure 2 Comparison of the number of individuals of each family 


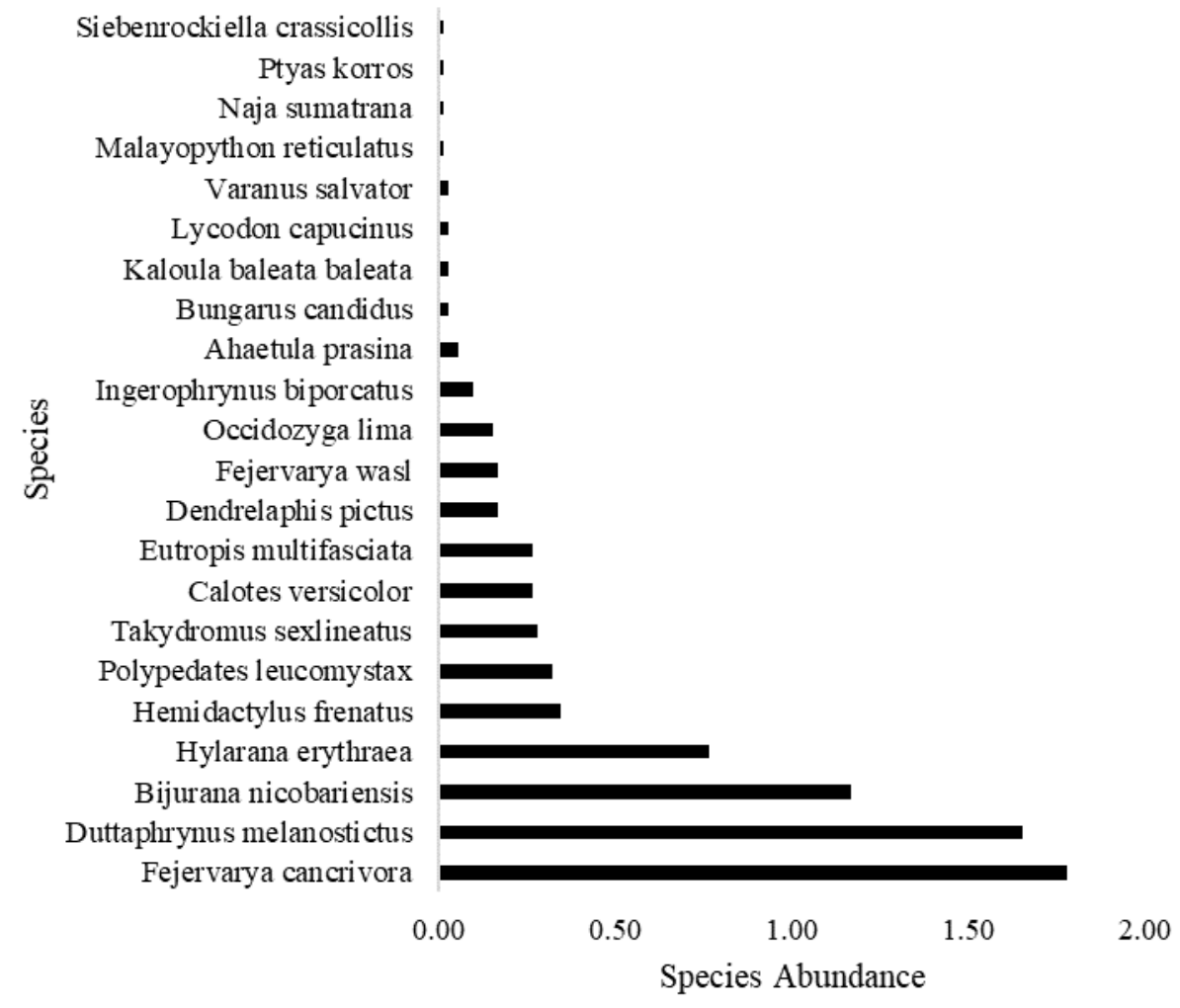

Figure 3 Herpetofa una species abundance (Individua1/hour of observer)

25

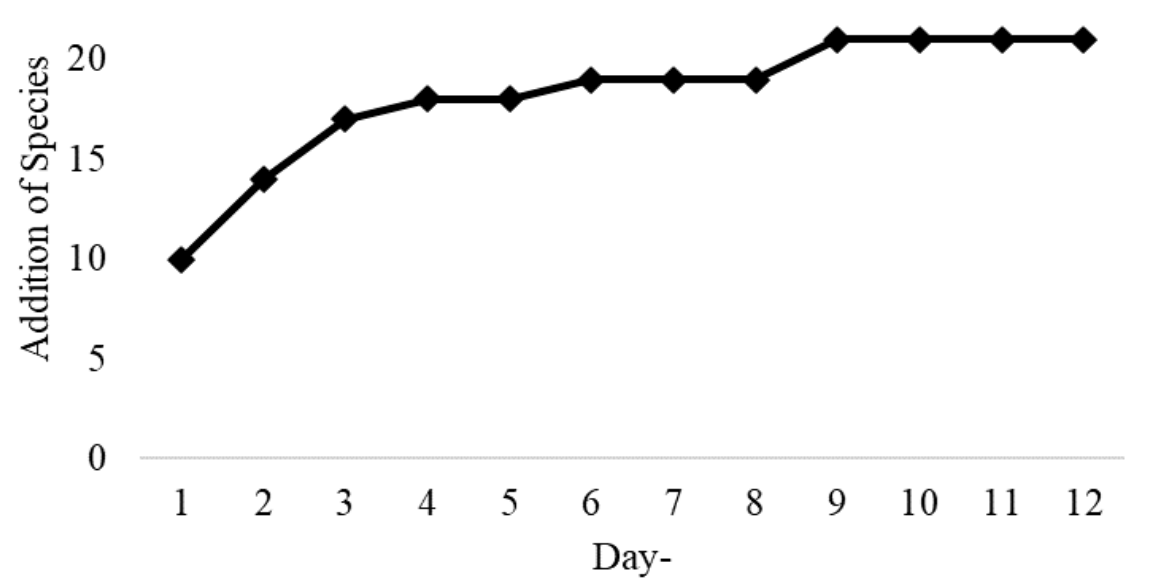

Figure 4 Addition of herpetofauna per-observation day

\section{Herpetofauna Distribution on Each Observation Path}

The ITERA area has open habitat condition. There are six permanent transects that are utilized to monitor the wildlife in ITERA, including herpetofauna. Path 1 is bordering the community's plantation, rivers, paddy fields, swamps, and mixed garden. Path 2 is high in activity and comes with arboretum forest and swamp areas. Path 3 has the most swamps, river flow, and shrubs. Path 4 and 5 have similar condition which are dominated by road access area and come with only one swamp on each path. Path 6 is located in the research area border; it has river flow, swamp, and shrubs. The herpetofauna research results in all paths found 550 individuals (Figure 5).

The analysis results of species distribution on each observation path showed that path 1 had the most species by 15 species. Path 3 and 5 had 14 species, path 2, 4, and 6 had 13 species (Figure 6). The difference of species 
distribution on each path is insignificant; this indicates that the habitat condition in ITERA tends to be the same and supports the herpetofauna distribution. Path 1 comes with the most species as it is the only path with diverse combinations, such as river, paddy field, swamp, shrubs, and mixed garden. In addition, it also has the least human activity.

There were eight herpetofauna (3 reptiles and 5 amphibians) found in all paths (Figure 6). The reptile species that could be found in all observation paths were Eutropis multifasciata, Takydromus sexlineatus, and Hemidactylus frenatus. E. multifasciata and $T$. sexlineatus were often found in shrubs area in ITERA and often caught in glue trap. These two types are cosmopolite and can live in open and disturbed area (Qurniawan et al. 2012). H. Frenatus is the most found reptile and often found on trees and in shrubs that support their live (McKay et al. 2009).

This study found six species that could only be found in one observation path. Malayopython reticulatus and Naja sumatrana (path 1); Kaloula baleata (path 2); Siebenrockiella crassicollis (path 3); Bungarus candidus and Ptyas korros (path 5). If seen through community similarity index analysis between paths using Jaccard index, path 4 and 5 had the highest community similarity level, which was by $80 \%$ (Figure 7). Path 4 and 5 had the highest community similarity because both paths had relatively similar habitat condition, which was dominated by road access with 1 swamp. Path 1 had the least similarity index because it came with diverse habitat condition compared to other paths. Thus, the herpetofauna was more varied than the other paths.

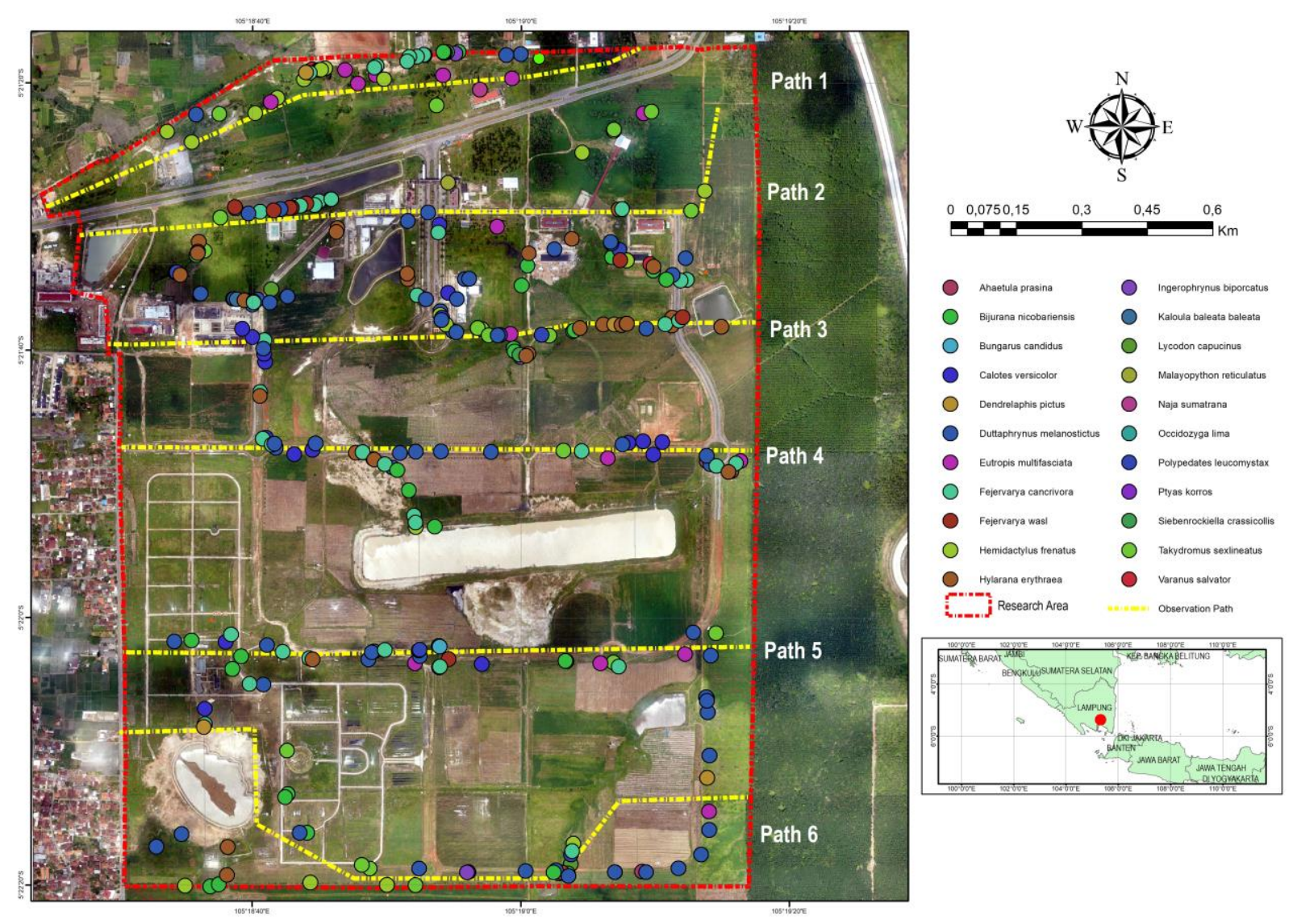

Figure 5 Distribution of herpetofauna encounters in ITERA area 


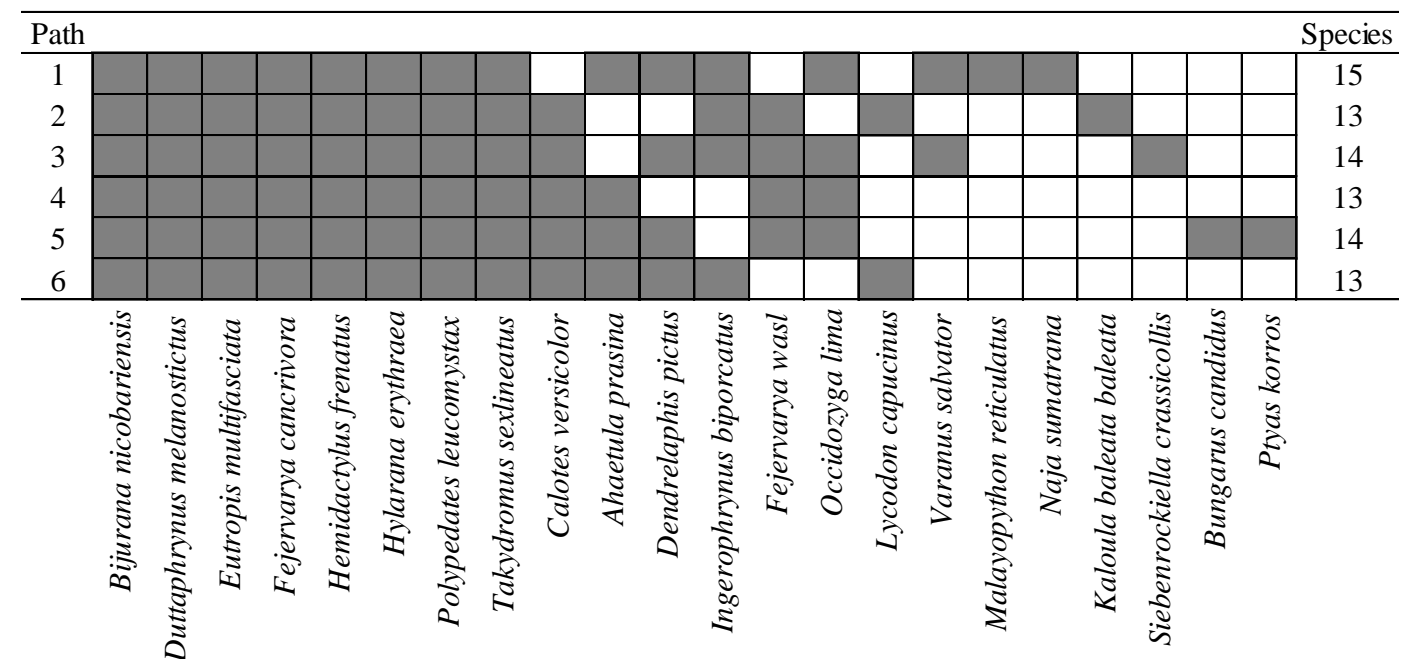

Figure 6 Herpetofauna species distribution in each observation path

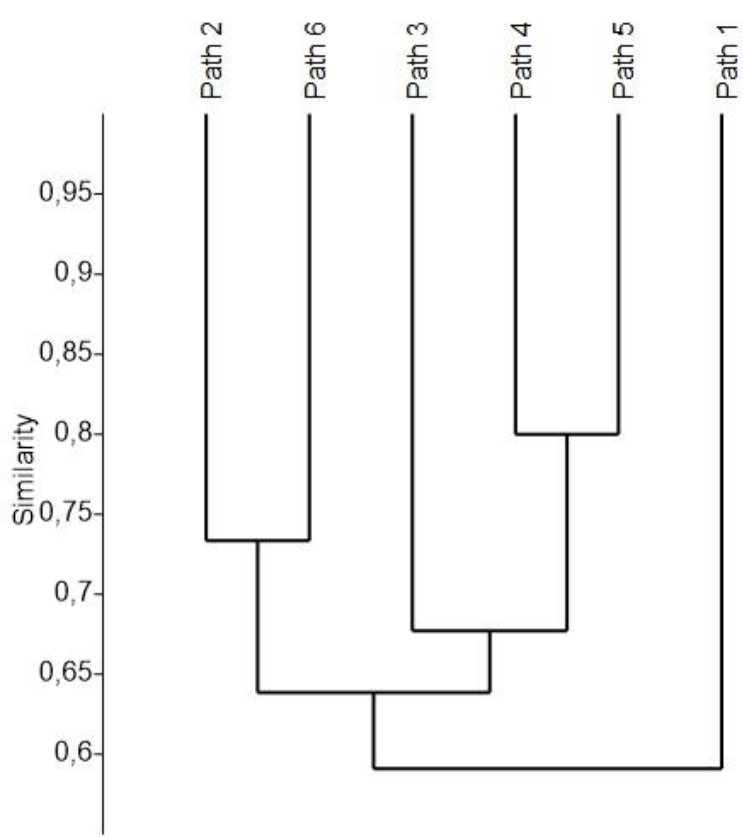

Figure 7 Jaccard community similarity index between paths

\section{CONCLUSION}

The wildlife research, especially in ITERA area is the first research conducted to assess the diversity level. Although there had been significant ecology changes in the development stage, 22 herpetofauna species that consisted of 9 amphibians and 13 reptiles were found in the research location. The amphibians found was 441 individuals of 5 families. While the reptile found was 109 individual of 9 families. One reptile was found under the vulnerable conservation status and 3 reptile species were included into CITES appendix II. The value of diversity index (H') was 2.29; species evenness (E) 0.74 ; and species richness 3.33. The amphibian class with the highest species abundance was Fejervarya cancrivora by
1.78 individual/hour of observer. While the highest species abundance in reptile class was Hemidactylus frenatus by 0.35 individual/hour of observer. Total herpetofauna encounters were 550 . There were 8 species that could be found in all paths and 6 species that were found only in one path. The biodiversity conservation activity in ITERA needs to be continued through time series monitoring to assure the forest campus development concept. Herpetofauna habitat in ITERA today is still considered supporting the life of herpetofauna. 


\section{ACKNOWLEDGMENTS}

This research is funded by Directorate of Research and Community Service, Ministry of Research and Technology/National Agency for Research. Contract Number: 009/SP2H/LT/DPRM/2020.

\section{REFERENCES}

Eprilurahman R. 2012. Cicak dan tokek di Daerah Istimewa Yogyakarta. Fauna Indonesia. 11(2): 23-27.

Fauzi MA, Hamidy A, Mumpuni, Kurniawan N. 2020. The threat of Appendix CITES-listed turtles harvesting in Central Borneo and South Sumatra. Journal of Tropical Life Science. 10(3): 215-222. doi: 10.11594/jtls.10.03.05.

Fitch HS.1992. Methods of sampling snake populations and their relative success. Herpetological Review. 23: 17-19.

Goris R, Maeda N. 2004. Guide to The Aamphibians and Reptiles of Japan. Krieger: Malabar.

Heltse JF, Forrester NE. 1983. Estimating species richness using the Jackknife procedur. Biometrsics. 39(1): 1-11.

Hortal J, Triantis KA, Meiri S, Thebault E, Sfenthourakis S. 2009. Island species richness increased with habitat diversity. American Naturalis. 174:E205E2017.

Irham M, Pungki L, Nur RI, Connie MS. 2012. Fauna Indonesia. Bogor: Masyarakat Zoologi Indonesia.

Iskandar DT. 1998. Amfibi Jawa dan Bali LIPI Seri Panduan Lapangan. Bogor: Puslitbang LIPI.

Kurniati H. 2008. Biodiversity and natural history of amphibians and reptiles in Kerinci Seblat National Park, Sumatra, Indonesia (2005, 2006, 2007, 2008) [report]. Bogor: Research Center for Biology-LIPI.

Kurniati H, Sulistyadi E. 2017. Kepadatan Populasi Kodok Fejervarya cancrivora di Persawahan Kabupaten Karawang, Jawa Barat. Jurnal Biologi Indonesia 13(1): 71-83.

Kurz DJ, Turner EC, Aryawan AA, Barkley HC, Caliman JP, Konopik O, Ps. S, Foster WA. 2016. Replanting reduces frog diversity in oil palm. Biotropica.48:483-490.

Kusrini MD. 2009. Pedoman Penelitian dan Survei Amfibi di Alam. Bogor: Fakultas Kehutanan, Institut Pertanian Bogor.

Kusrini MD. 2019. Metode Survey dan Penelitian Herpetofauna.Bogor: IPB Press.
Larson DM. 2014. Grassland fire and cattle grazing regulate reptile and amphibian assembly among patches. Environmental Management. 54:1434-1444.

Magurran AE. 1988. Ecological Diversity and Its Measurement. New Jersey: Princeton University Press.

McKay JL, Griffths AD, Crase B. 2009. Distribution and habitat use by Hemidactylus frenatus Duméril and Bibron (Gekkonidae) in the Northern Territory, Australia. The Beagle, Records of the Museums and Art Galleries of the Northern Territory. 2009(25): 111-116.

Mistar. 2008. Panduan Lapangan Amfibi dan Reptil di Areal Mawas Provinsi Kalimantan Tengah (Catatan di Hutan Lindung Beratus). Kalimantan Tengah: Yayasan Penyelamatan Orangutan Borneo.

Murray-Dickson G, Ghazali M, Ogden R, Brown R, Auliya M. 2017. Phylogeography of the reticulated python (Malayopython reticulatus ssp.): Conservation implications for the worlds' most traded snake species. PLOS ONE. 12(8): e0182049. https://doi.org/10.1371/journal.pone.0182049.

Qurniawan TF. 2015. Model of microclimatic influence on fluctuation of herpetofauna diversity in camps area. Jurnal teknosains. 4(2): 172-178.

Qurniawan TF, Addien FU, Eprilurahman, Trijoko. 2012. Eksplorasi keanekaragaman herpetofauna di Kecamatan Girimulyo, Kabupaten Kulon Progo, Yogyakarta. Jurnal Teknosains. 1(2) 7-143.

Stein A, Gerstner K, Kreft H. 2014. Environmental heterogenity as a universal driver of species richness across taxas, biomes,and spatial scales. Ecology Letters. 17(2014): 866-880.

UNEP WCMC (United Nation Environment Programme World Conservation Monitoring Center. 2007. Indonesia: A Review of trade in CITES-listed species. Cambridge: UNEP World Conservation Monitoring Centre.

US Department of Agriculture. 2006. Land Resource Regions and Major Land Resource Areas of the United States, the Caribbean, and the Pacific Basin. United States Department of Agriculture, Natural Resources Conservation Service Handbook 296: Washington DC.

Wanger TC, Iskandar DT, Motzke I, Brook BW, Sodhi NS, Clough Y, Tscharntke T. 2009. Effects of landuse change on community composition of tropical amphibians and reptiles in Sulawesi, Indonesia. Conservation Biology. 22:375-384. 